\title{
The Interactive Relationship of Transnational Technology Transfer \& Diffusion and National Innovation Capability_ The Johansen Co-integration and Granger-Causality Relationship Test Based on China's Open Innovation System Construction
}

\author{
${\text { Yan } \text { Chang }^{1} \text { \& Xinjian Cui }}^{1}$ \\ ${ }^{1}$ School of business, Central University of Finance and Economics, China \\ Correspondence: Yan Chang, School of Business, Central University of Finance and Economics, Beijing, China. \\ E-mail: emily_chang@126.com
}

Received: September 13, 2013

Accepted: October 10, 2013

Online Published: October 15, 2013

doi:10.5539/ijbm.v8n21p76

URL: http://dx.doi.org/10.5539/ijbm.v8n21p76

\begin{abstract}
With the strengthen of the world's economic and social linkage, the traditional closed innovation system is outdated, and we must accelerate global innovation network construction and build an open national innovation system in order to enhance the national innovation capability more effectively. This paper establishes its research concepts and theoretical framework firstly, and analyzes the nine function route of transnational technology transfer \& diffusion on national innovation capability theoretically, which forming a "234" structure, then use the sample data 1993-2011 of China, it empirically tests the Johansen co-integration and Granger -causality relationship between transnational technology transfer \&diffusion and national innovation capability. According to the analysis and empirical study, we draw the following conclusions: (1) There exist long-term equilibrium relationships and different Granger-causality relationships between transnational technology transfer \&diffusion and national innovation capability. (2) Whether in short-term or long-term, the promotion of international trade or national innovation capability can promote the other side, that's mean the promotion function between each other is both current effects and long-term effects, so it is a win-win relationship between international trade and national innovation capability. (3) In the short term (2 years), foreign direct investment and national innovation capability can promote each other. But in the long term ( 3 years and above), national innovation capability can promote the growth of foreign direct investment, while the growth of foreign direct investment can not enhance the national innovation capability effectively. (4) In a very short period (1 year and less), it can enhance national innovation capability shortly to increase the transnational R\&D institutions to embed into the host country. But in a longer term ( 2 years and above), there does not exist promote function each other between transnational R\&D institutions embedding and national innovation capability, and the multinational R\&D institutions embedding only has a very limited short-term effect on the host country's national innovation capability building, and there is no very obvious long-term positive effects.
\end{abstract}

Keywords: transnational technology transfer \& diffusion, national innovation capability, johansen co-integration relationship, granger-causality relationship

\section{Introduction}

Nowadays, the international competition becomes more and more increasingly worldwide, so the national innovation capability of one country or region becomes the key of core competence and its sustainable development capability. Enhancing national innovation capability and building a national innovation system get more and more world attention and focus. National innovation system refers to the innovation network in a country which interacts between the departments and agencies to promote innovation, which is composed of economic, scientific and technological organizations (Zheng, 2006). However, in the era of big data, information and knowledge spreads very rapidly, knowledge interaction and information sharing are playing an increasingly important role, and different countries have increasingly close ties each other, the integration trend of the world economy is growing outstanding. In this new situation, the traditional closed national innovation system has been unable to meet the needs of modern economic and social development, and it must be an open stance to build a national innovation system, and we must actively integrate into the global innovation system, participate 
in the global innovation chain in the world, seek cooperation for their development in the global innovation networks. So building an open national innovation system has become increasingly important, and it has strategic significance increasingly. The construction of an open national innovation system gives greater emphasis on foreign openness and inclusiveness than the traditional national innovation network construction, so its focus on openness is reflected in the international innovation cooperation and sharing, and it is reflected in transnational technology transfer and diffusion specifically. In order to study the impact of transnational technology transfer and diffusion on national innovation capacity building in open innovation environment, on the basis of concept definition, this paper uses Chinese practice of open innovation system construction as the research object, tests the Johansen co-integration and causality relationship between transnational technology transfer \&diffusion and national innovation capability empirically, and it tries to reveal function rules of the transnational technology transfer and diffusion on national innovation capability, and so as to propose more practical-oriented policy recommendations.

\section{Literature Review}

The research on the influence of transnational technology transfer to the host country's innovative capability mainly focuses in the following two kinds of ideas. Some scholars hold that it is beneficial for the improvement of the innovation capability of the host country. And other scholars hold that it is not conducive to for the improvement of the innovation capability of the host country (Yan, 2010).

The earlier scholars believed that the spillover effect of transnational corporations (TNCs) into the host countries, especially the developing host countries is weak, and it is not conducive to the technology development of the developing countries. As Moran (1978), Lall (1987) and Streeten (1977) pointed out: because multinational corporations generally do not use the most advanced technologies in the developing subsidiaries or affiliates, the technologies they used in the host country, especially used in the developing host country, generally are low level of production technology, so multinational corporations direct investment in the developing countries can lead to these countries occupied their domestic market, and make detriment of the host country's technological development. Hymer considered (1970), multinational foreign direct investment is an international expansion of their domestic dominance, and the expansion of dominance itself is a market distortion, it will produce a poor anti-competitive effects, and it does not conducive to the growth and development of technology. Later studies in a mainstream perspective emphasizes the growth of multinational technology to the host country has a positive effect. They hold multinational corporations have advanced technology and skills, and also are the primary agents of technology transfer. The investment and production activities of multinational corporations will generate positive effects of competition in the host country, externalities and spillovers. Therefore, it has great role in promoting technology growth of the host country because of the entrance and presence multinational companies.

Wang \& Blomstrom (1992) hold that the multinationals and the host country enterprises can realize the cost of technology diffusion, both of them may affect technology spillovers level through their investment decisions. Das (1987) proved theoretically that, although it has uncertain influence on local firms' profits and yield for the multinationals to use advanced technology, but in general, it will increase the welfare of the people of the host country, the host country economy will be developed. Therefore, it is beneficial for the host economy development and the people to transfer the technology internationally. JIANG Xiaojuan (Jiang \& Li, 2002; Jiang, 2004) holds that multinational companies has an irreplaceable role in helping Chinese local management and technical staff to improve the ability to grasp the business opportunities and to determine knowledge. Peng \& Liu, 2003) found that multinational companies in the field of advanced technology is still strict blockade to China, their role to enhance the level of industrial technology in China is very limited regardless spillovers of technology transfer to China, or the establishment of R\&D institutions in China's initiatives.

In recent years, the view of scholars shows a bit compromise trend, they are neither deny the entry of multinationals will promote the technology growth of the host country, but also stress that technology does not automatically flow into the host country along with the inflow of FDI inflows, and technology transfer \&diffusion has multiple constraints conditions. Overall, most economists believe overseas FDI activities of transnational corporations have a positive impact on innovation systems of the host countries, and they have both direct and indirect effects for the host country technological advances. Indirect impact is mainly manifested in "competition effect", "learning effect", "cluster effect" and "open effect". Some scholars and institutions emphasize Multinational FDI have a "crowding out" effect on host country's innovation systems, mainly they will take up the technological resources of the host country, make the loss of dominance in technology of the host country, get technology benefit of the host country. 
In short, regardless transnational technology transfer or transnational technology diffusion, there are two diametrically opposed views about its ability to enhance the host country's innovation capability, but most scholars now are more in favor of compromise view, that is it will have promotion function on national innovation capability building, but depending on the specific circumstances and conditions.

\section{The Establishment of the Research Definition and Framework}

\subsection{The Connotation Transnational Technology Transfer \& Diffusion}

Technology Transfer refers the inputs and outputs active process of technology within the system of the country, region or within the industry and between the technology system itself. It includes the transfer, transplantation, absorption, communication and popularization of technology, technological achievements, information, and some ability. Technology transfer has a lot of ways, and they can be broadly grouped into the following categories: technology license, industry-university-research combination, equipment and software acquisition, information dissemination, technical assistance, the creation of new business, business incubators etc. Transnational technology transfer refers to the technology flowage in different countries or regions (Xie \& Zheng, 2000). Technology diffusion is a technique to get from the first commercial application, through promotion efforts, widespread adoption stage, until the final result of the process of being eliminated backwardness. It not only refers to the production technology is simple to obtain, but the emphasis on the introduction of technology's technical capability building activities. Technology diffusion occurs after technological progress and technological innovation, and is relative with the technological innovation in the market promotion and communication processes (Chen \& Wu, 1999). Transnational technology transfer and diffusion is the manifestation of technology transfer and diffusion between countries (or between regions), and it is international flowage of technology, and knowledge (Xie, 2002). In the knowledge economy, economic interdependence between countries, transnational knowledge, capital and technology flows become more frequent, transnational technology transfer and diffusion become the important factors of open national innovation system and also become an important driving force of a national innovation capability.

\subsection{The Connotation of National Innovation Capability}

Innovation capability is the ability that use of knowledge and theories in science, art, technology and a variety of practical activities in the field continue to provide an economic value, social value, ecological value of new ideas, new theories, new methods and new inventions. Innovation capability can be divided into national innovation capability, regional innovation capability, enterprise innovation capability, and there are multiple innovation index rankings measuring innovation capability (Xie, 2002). National innovation capability is a country's capability of developing and applying scientific and technical, mainly reflect in the research and development capabilities of crafts process, product design, and it is the formation and application capability of a country in new technologies, new products, new materials, new crafts, new processes, new methods and other aspects (Wang \& Zhang, 2002). The constitution of national innovation capability has different partition dimensions, from input-output perspective, it can be divided into research and development capability, the transformation capability and market share capability of scientific and technological innovation; from point of view the system function of the national innovation, it can be divided into knowledge creation capability, knowledge dissemination capability and knowledge application capability; from the system elements participation and synergy perspective, it can be divided into information capability, technology capability, organizational capability and institutional capability. In the knowledge economy era, national innovation capability has become the most important drivers of a national sustainable development, so every country attaches great importance to national innovation capability building.

\subsection{Core Measuring Indicators Setting}

This paper attempts to analyze the Johansen co-integration and Granger causality relationship between transnational technology transfer \& diffusion and national innovation capability, so we need to define measuring indicators firstly. In order to avoid cumbersome setting up and calculating indicators, highlighting key indicators, this article uses KPI (key performance indicators) designed measuring indexes. Based on the above analysis, we define as follows:

\subsubsection{The Measurement of Transnational Technology Transfer \& Diffusion}

According to the existing theoretical results, the generally considered major channels of transnational technology transfer \& diffusion includes international trade, foreign direct investment and cross-border establishment of R\&D institutions (we defined here as transnational R\&D institutions embedding). Along with these three key factors, technology and knowledge transfer will occur dissemination and diffusion, and thus 
leads to corresponding impact on the national innovation capability. To measure international trade, foreign direct investment and transnational R\&D institutions embedding (Cui, 2011), respectively, using the following three aspects of key indicators: using the total import and export of goods to measure international trade, using the actual use of foreign direct investment to measure FDI, using the number of R\&D institutions of foreign enterprises in China to measure the transnational R\&D institutions embedding.

\subsubsection{The Measurement of National Innovation Capability}

The composition of national innovation capability includes many aspects, according to the U.S. "innovation indicators", "national innovation capability evaluation report", Global Innovation Index and other measurement system, which comprises at least two aspects of the inputs and outputs of multiple targets. This paper holds that the most critical national innovation capability reflects in innovation output and performance, while the most important output performance is reflected in the patent. Therefore, this paper Three Kinds of Patents Granted indicators as a measure of national innovation capacity index.

\subsection{The Functional Mechanism of Transnational Technology Transfer and Diffusion on National Innovation Capability}

According to our definition, transnational technology transfer and diffusion mainly happen through three ways: international trade, foreign direct investment and multinational R\&D institutions embedding. So we analyze the functional mechanism and the relationship of transnational technology transfer and diffusion on national innovation capability also from the above three aspects.

The functional mechanism of International trade on national innovation capability can be described as the following two paths: (1) direct effect, that means the implicit technology and knowledge in the products or services has been applied in the markets of the importing countries directly through international trade, and they enhance the national innovation capability of the importing country directly; (2) indirect effect, because of the export bringing market competition intensifies, it will stimulate other related corporations or innovation bodies in the importing country to strengthen R\&D and innovate in order to gain market advantage, but also it will stimulate the enterprises of the exporting country to strengthen technology research and development in order to enhance the competitiveness of products in the market so as to gain export market advantage.

The functional mechanism of FDI on the national innovation capability can be described as the following three paths: (1) the precipitate technology and knowledge formed in the initial investment; (2) the technology transfer and diffusion in the process of sustainable development, to some extent it has established and formed a technology and knowledge transferring channel between the home and host countries, and it will continue to make the latest technology and knowledge transfer to the host country; (3) the new knowledge and new technologies which formed in the activities in the host country when they are involved in the economic activities, thereby they will form the host country's innovation capability directly.

The functional mechanism of transnational R\&D institutions embedding on the national innovation capability can be described as the following four paths: (1) It is directly embedded in the host country national innovation system, so as to enhance the function of the innovation system of the host country; (2) It forms a long-term path of technology diffusion of the home country, which will form technology spillover effect; (3) It will stimulate the main innovation bodies of the host country to accelerate the pace of innovation in order to gain market advantage; (4) the intellectual property rights formed in the foreign institutions' R\&D and innovation activities, will applied in the host country market so as to enhance the innovation performance of the host country. Chang $\&$ Chen $(2011 ; 2010 ; 2008)$ The above described basic mechanisms are shown in Figure 1. 


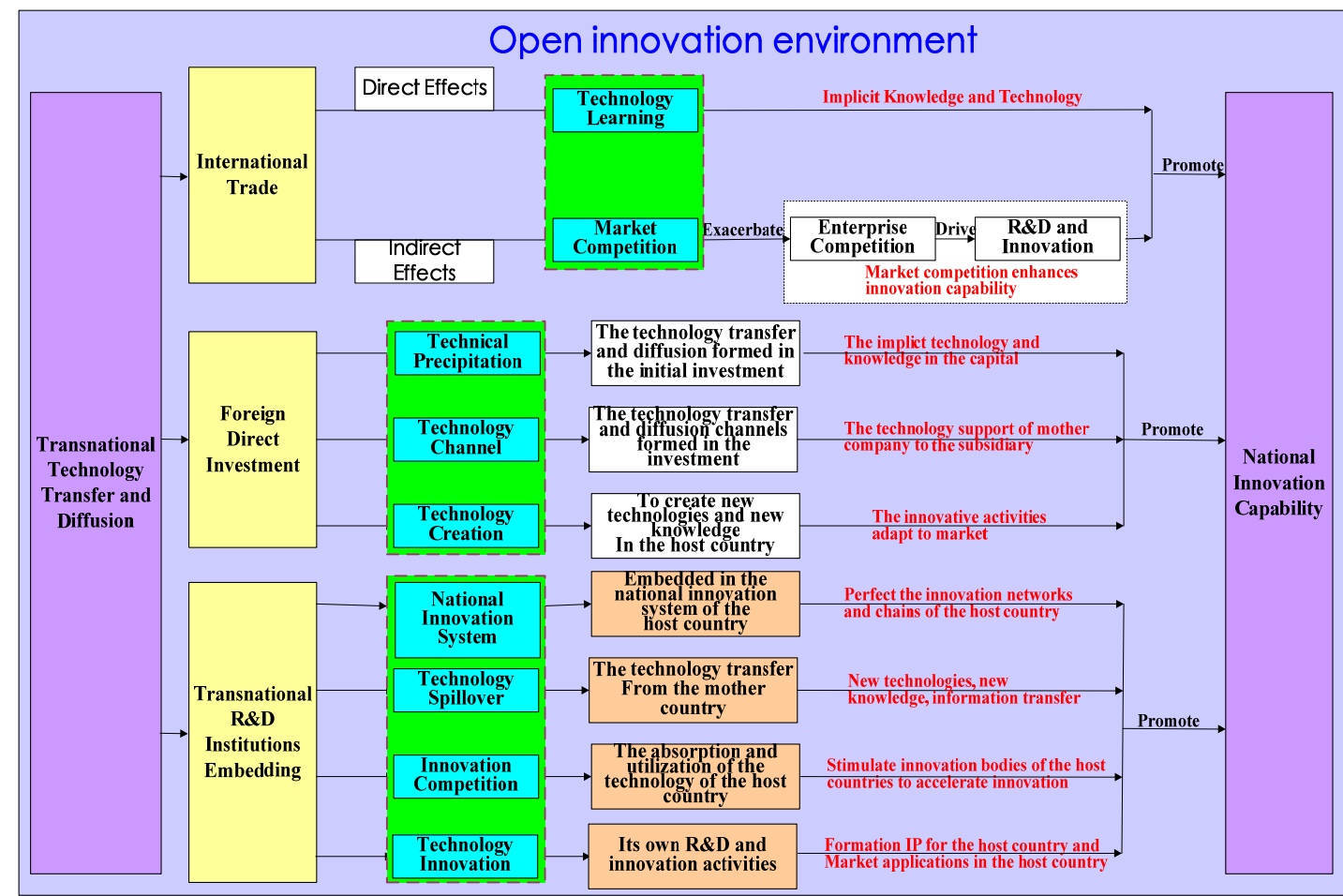

Figure 1. The function paths of transnational technology transfer and diffusion on the innovation capability of the host country

According to the research framework and function mechanism analysis and definition, we believe that the three key elements (international trade, foreign direct investment and transnational R\&D institutions embedding) of transnational technology transfer and diffusion has promoting function on national innovation capability of the host country, and there exist long-term equilibrium relationship (co-integration) between them. The change of one element could lead to the changes of another element; especially the changes of relevant dimensions of transnational technology transfer \& diffusion may induce the changes or improvement of the national innovation capability of the host country. In turn, the improvement of national innovation capability of the host country may also stimulate and attract more transnational technology transfer and diffusion. At the same time, there may be some lag when transnational technology transfer and diffusion make effect on national innovation capability of the host countries, namely there exists lead-lag relationship (Granger causality) between transnational technology transfer \& diffusion and national innovation capability. To validate our theoretical analysis and assumptions on the relationship between them, this paper tests the Johansen co-integration and Granger causality relationship between transnational technology transfer \& diffusion and national innovation capability using China as study example (Chen, He \& Wang, 2011).

\section{Methodologies and Data Acquisition}

\subsection{Research Methods Introduction}

\subsubsection{Unit Root Test (ADF test)}

ADF test is proposed by Dickey and Fuller, and it is a statistical analysis method for testing the smoothness of stationary time series. ADF model is:

$$
\Delta X_{t}=\alpha+\beta \Delta X_{t-1}+\sum_{i=1}^{n} \delta_{i} \Delta X_{t-i}+\varepsilon_{t}
$$

Where $\Delta X_{t}=X_{t}-X_{t-1}, \Delta X_{t-i}=X_{t-i}-X_{t-i-1}$, the selection criteria of $\mathrm{n}$ is no autocorrelation residuals of $\varepsilon_{t}$. The null hypothesis of $\mathrm{ADF}$ test is $\mathrm{H}_{0}$ : $\beta=0$ (i.e., the time series is non-stationary), the alternative hypothesis is $\mathrm{H}_{0}$ : $\beta<0$. If $\mathrm{H}_{0}$ is rejected, it indicates that $\mathrm{X}_{\mathrm{t}}$ is stationary, if $\mathrm{H}_{0}$ is accepted, then $\mathrm{X}_{\mathrm{t}}$ is non-stationary, and ADF test 
critical value can be obtained through the look-up table.

\subsubsection{Johansen Co-integration Test}

Co-integration revealed a long-term stable equilibrium relationship. The economic variables meeting co-integration will not be apart too far from each other. A shock can only make them deviate from the equilibrium position within a short time, in the long term they will automatically revert to a balanced position. Co-integration test is a prerequisite condition for the establishment of economic model, and it is the study basis of testing Granger causality between the variables. There are two main ways about testing co-integrate relationship between the variables: Engle-Granger two stage co-integration test method and the Johansen co-integration test method. This paper uses the Johansen co-integration test method to test the co-integration relationship between transnational technology transfer \& diffusion and national innovation capability.

\subsubsection{Granger Causality Test}

Co-integration analysis only can conclude if there exists long-term stable relationship between the variables. Even there exists long-term stable relationship between the variables, it only shows that they are at least one direction of causality, and can not explain the accurate direction of causality between the variables, i.e. it does not give a Lead-Lag relationship between the variables. Granger causality test method can solve this problem and it is able to test that if the lead-lag relationship is unidirectional or bidirectional qualitatively. Therefore it is necessary to make a Granger causality test for transnational technology transfer \& diffusion and national innovation capability so as to verify transnational technology transfer \& diffusion is the reason of the improvement of national innovation capability.

\subsection{Research Data Acquisition}

In order to analyze the co-integration and causality relationship between transnational technology transfer \& diffusion and national innovation capability, according to the measuring index system design of this study, we got the data of total imports and exports goods, the actual use of foreign direct investment, Three Kinds of Patents Granted and foreign enterprises in China's R\&D institutions from 1993 to 2011, from "China Statistical Yearbook" and the Ministry of Commerce website and related information data. The original data of the above key indicators are shown in Figure 2-5.

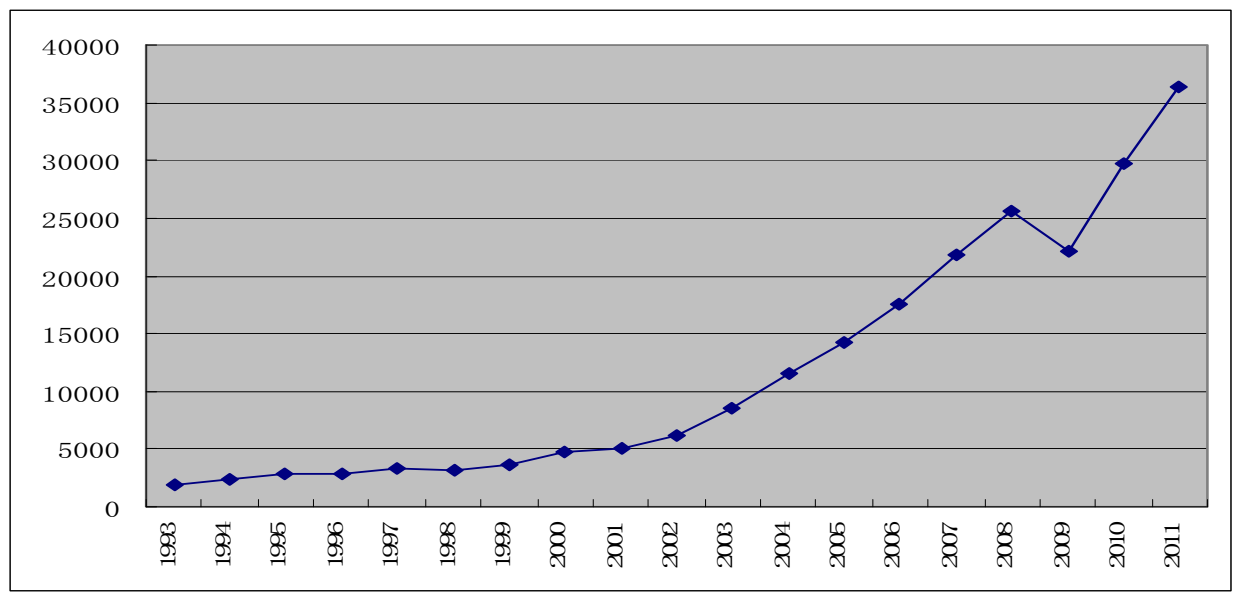

Figure 2. International trade situation (unit: 100 million U.S. \$) 


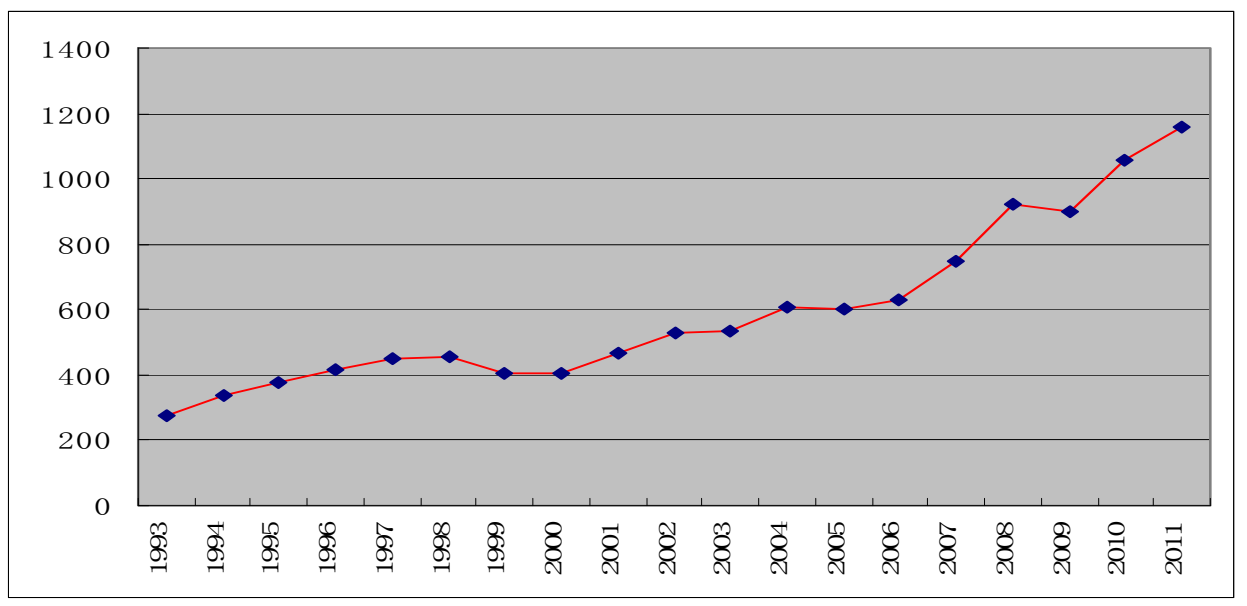

Figure 3. Foreign direct investment situation (unit: 100 million U.S. \$)

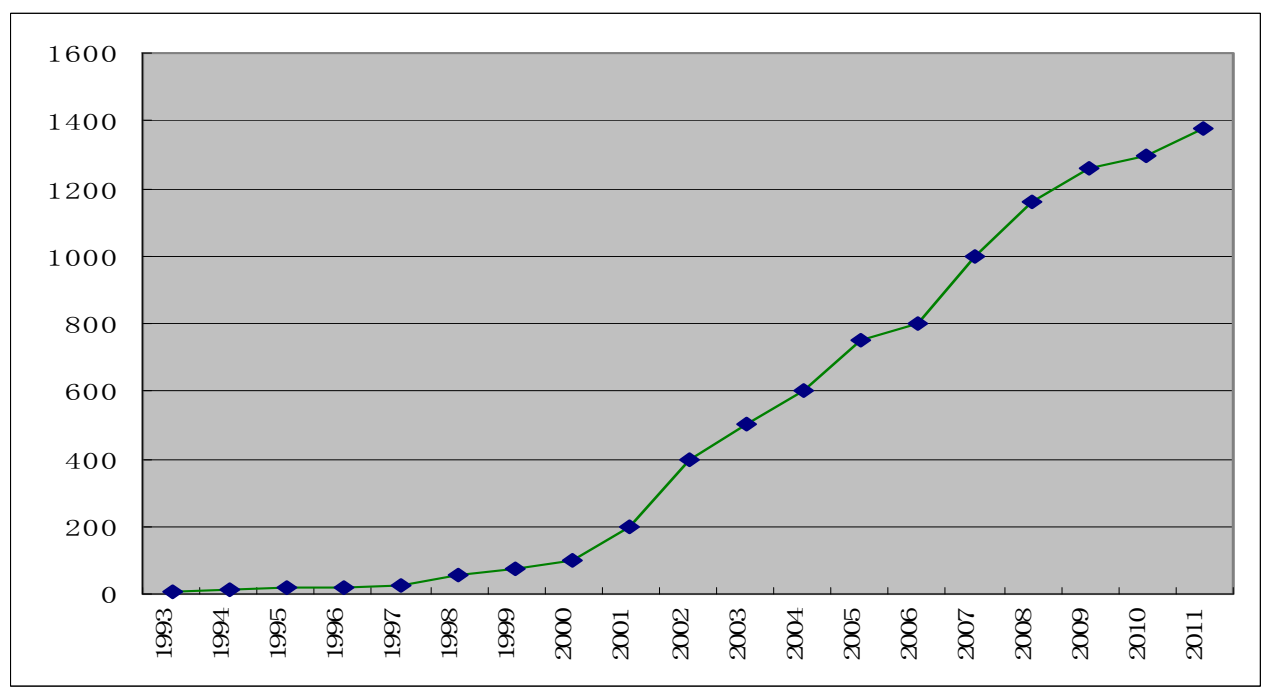

Figure 4. The situation of transnational R\&D institutions embedded in (unit: number)

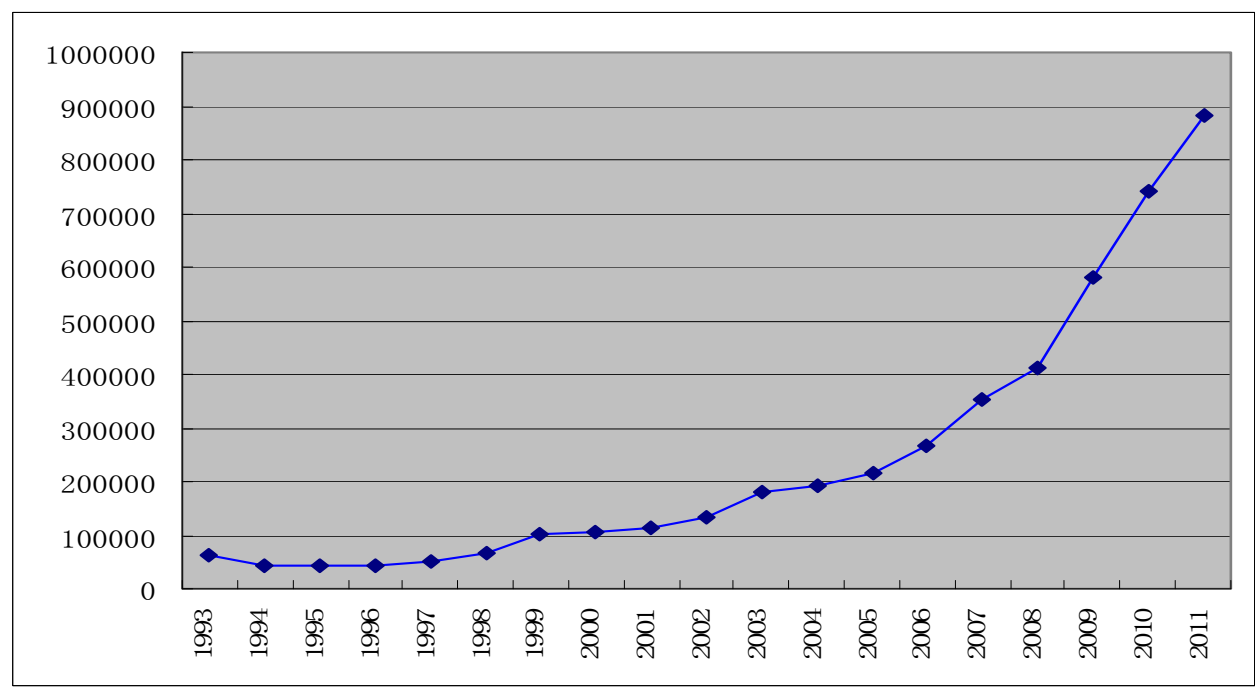

Figure 5. National innovation capability situation (unit: piece) 


\section{The Johansen Co-Integration Relationship Test of Transnational Technology Transfer \& Diffusion and National Innovation Capability}

This paper wants to verify the Johansen co-integration and Granger causality relationship between transnational technology transfer \& diffusion and national innovation capability. Before Granger causality test we must test the stationary of time series data using the unit root test, and then use the Johansen co-integration test to determine whether there is co-integration relationship between the variables, and finally use Granger causality test to verify Granger causality relationship between the variables. We use Eviews 5.0 as the analytical tool (Wang \& Chen, 2010).

\subsection{ADF Test of the Data Sequence}

To make sure whether the data is stationary suitability for co-integration and Granger causality test, we make $\mathrm{ADF}$ test of the three elements (international trade, foreign direct investment, multinational R\&D institutions embedding) of transnational technology transfer \& diffusion with national innovation capability data sequence (Chen \& Wang, 2010). Table 1 shows the ADF test results. From the test results in Table 1 we can find that:

(1) Whether at the critical value of $1 \%, 5 \%$ or $10 \%$, the null hypothesis (i.e., the time series are non-stationary) of the national innovation capability, international trade, transnational R\&D institutions embedding and its first difference sequence can not be rejected (ADF test critical value is greater than $10 \%$ critical value). This indicates that the sequence of national innovation capability, international trade, transnational R\&D institutions embedding and its first difference sequence are non-stationary series. Whether at the critical value of $1 \%, 5 \%$ or $10 \%$, the null hypothesis (i.e., the time series are non-stationary) of the national innovation capability, international trade, transnational R\&D institutions embedding and its second-order difference sequence was rejected (ADF test critical value is less than the critical value of $1 \%, 5 \%, 10 \%$ ). This indicates that the national innovation capability, international trade, and transnational R\&D institutions embedding sequence is second-order stationary process.

(2) Whether at the critical value of $1 \%, 5 \%$ or $10 \%$, the null hypothesis (i.e., the time series are non-stationary) of foreign direct investment can not be rejected (ADF test critical value is greater than $10 \%$ critical value). This indicates that the sequence of foreign direct investment is non-stationary series. At the critical value of $5 \%$ and $10 \%$, the null hypothesis (i.e., the time series are non-stationary) of the first difference sequence of foreign direct investment can be rejected (ADF test critical value is less than $5 \%$ and $10 \%$ critical value, but it is greater than $1 \%$ critical value). This indicates that the sequence of the first difference sequence of foreign direct investment is stationary series at $5 \%$ and $10 \%$ critical value, but it is non-stationary series at $1 \%$ critical value. Whether at the critical value of $1 \%, 5 \%$ or $10 \%$, the null hypothesis (i.e., the time series are non-stationary) of the second difference sequence of foreign direct investment was rejected (ADF test critical value is less than the critical value of $1 \%$ ). This indicates that the sequence of the second difference sequence of foreign direct investment is stationary series.

According to the above analysis, we can conclude that international trade, foreign direct investment, transnational national $\mathrm{R} \& \mathrm{D}$ institutions embedding and national innovation capability are second-order stationary process. 
Table 1 . ADF test results of the data series

\begin{tabular}{lcccc}
\hline \multicolumn{1}{c}{ Series Name } & ADF Test & 1\% Critical & 5\% Critical & 10\% Critical \\
& Statistic & Value & Value & Value \\
\hline National innovation capability & 7.8270 & -3.8574 & -3.0404 & -2.6606 \\
The first difference of National innovation capability & -0.84579 & -3.8868 & -3.0522 & -2.6666 \\
The second difference of National innovation capability & -5.49797 & -3.9204 & -3.0656 & -2.6735 \\
International trade & 2.388076 & -3.8574 & -3.0404 & -2.6606 \\
The first difference of International trade & -0.892005 & -3.9591 & -3.0810 & -2.6813 \\
The second difference of International trade & -5.510288 & -3.9591 & -3.081 & -2.6813 \\
Foreign Direct Investment & 1.657041 & -3.8574 & -3.0404 & -2.6606 \\
The first difference of Foreign Direct Investment & -3.528455 & -3.8868 & -3.0522 & -2.6666 \\
The second difference of Foreign Direct Investment & -4.62521 & -3.9591 & -3.081 & -2.6813 \\
Transnational R\&D institutions Embedding & 1.858509 & -3.8574 & -3.0404 & -2.6606 \\
The first difference of Transnational R\&D institutions Embedding & -2.367039 & -3.8868 & -3.0522 & -2.6666 \\
The second difference of Transnational R\&D institutions Embedding & -5.374132 & -3.9204 & -3.0656 & -2.6735 \\
\hline
\end{tabular}

\subsection{Johansen Co-Integration Test}

Through the above ADF unit root test, we have come to the conclusion that national innovation capability, international trade, foreign direct investment and transnational R\&D institutions embedding are second-order stationary process, so we can take Johansen co-integration test. The following step, we will test the co-integration relationship between the three key elements (international trade, foreign direct investment, transnational R\&D institutions embedding) of transnational technology transfer \& diffusion and national innovation capability (Wang \& Chen, 2008). Table 2 shows the Johansen co-integration test results of the three elements of transnational technology transfer \& diffusion and national innovation capability.

Table 2. The Johansen co-integration test results of the three elements of transnational technology transfer \& diffusion and national innovation capability

\begin{tabular}{|c|c|c|c|c|}
\hline Eigenvalue & $\begin{array}{c}\text { Trace } \\
\text { Statistic } \\
\end{array}$ & $\begin{array}{c}5 \text { Percent } \\
\text { Critical Value } \\
\end{array}$ & $\begin{array}{c}1 \text { Percent } \\
\text { Critical Value } \\
\end{array}$ & $\begin{array}{l}\text { Hypothesized } \\
\text { No. of CE (s) }\end{array}$ \\
\hline \multicolumn{5}{|c|}{ International trade and National innovation capability } \\
\hline \multicolumn{5}{|c|}{ Lags interval: No lags } \\
\hline 0.902920 & 45.99016 & 15.41 & 20.04 & None $* *$ \\
\hline 0.199714 & 4.010140 & 3.76 & 6.65 & At most $1 *$ \\
\hline \multicolumn{5}{|l|}{ Lags interval: 1 to 1} \\
\hline 0.739777 & 23.08385 & 15.41 & 20.04 & None $* *$ \\
\hline 0.011591 & 0.198201 & 3.76 & 6.65 & At most 1 \\
\hline \multicolumn{5}{|c|}{ Foreign direct investment and National innovation capability } \\
\hline \multicolumn{5}{|c|}{ Lags interval: No lags } \\
\hline 0.896333 & 48.54716 & 15.41 & 20.04 & None $* *$ \\
\hline 0.349812 & 7.748883 & 3.76 & 6.65 & At most $1 * *$ \\
\hline \multicolumn{5}{|l|}{ Lags interval: 1 to 1} \\
\hline 0.544729 & 13.53807 & 15.41 & 20.04 & None \\
\hline 0.00948 & 0.161387 & 3.76 & 6.65 & At most 1 \\
\hline \multicolumn{5}{|c|}{ Transnational R\&D institutions embedding and National innovation capability } \\
\hline \multicolumn{5}{|c|}{ Lags interval: No lags } \\
\hline 0.859400 & 38.81009 & 15.41 & 20.04 & None $* *$ \\
\hline 0.176571 & 3.496999 & 3.76 & 6.65 & At most 1 \\
\hline \multicolumn{5}{|l|}{ Lags interval: 1 to 1} \\
\hline 0.504885 & 11.99705 & 15.41 & 20.04 & None \\
\hline 0.002739 & 0.046635 & 3.76 & 6.65 & At most 1 \\
\hline
\end{tabular}

Trace test indicates 2 cointegrating equation(s) at the $5 \%$ level; Trace test indicates 1 cointegrating equation(s) at the $1 \%$ level; *(**) denotes rejection of the hypothesis at the $5 \%(1 \%)$ level.

From Table 2 we can find that: (1) The null hypothesis $r \leq 0$ can not be rejected (the trace statistics are larger than the critical value of $5 \%$, but there is one less than the critical value of $1 \%$ ), and the null hypothesis $r \leq 1$ 
can not be rejected (at least one trace statistic is less than the critical value of $1 \%$ and $5 \%$ ). This shows that there exists Johansen co-integration relationship between international trade and national innovation capability. That means national innovation capability and international trade may deviate from the equilibrium state in a short period, but in the long term, there maintains a balanced relationship between national innovation capability and international trade. (2) The null hypothesis $r \leq 0$ is rejected (the trace statistics are larger than the critical value of $1 \%$ and $5 \%$ ), and the null hypothesis $r \leq 1$ can not be rejected (the trace statistics were less than the critical value of $1 \%$ and $5 \%$ ). This shows that there exists Johansen co-integration relationship between foreign direct investment and national innovation capability. That means national innovation capability and foreign direct investment may deviate from the equilibrium state in a short period, but in the long term, there maintains a balanced relationship between national innovation capability and foreign direct investment. (3) The null hypothesis $r \leq 0$ can not be rejected (at least one trace statistic is less than the critical value of $1 \%$ and $5 \%$ ), and the null hypothesis $r \leq 1$ can not be rejected (trace statistics were less than the critical value of $1 \%$ and $5 \%$ ). This shows that there exists Johansen co-integration relationship between transnational R\&D institution embedding and national innovation capability. That means national innovation capability and transnational R\&D institution embedding may deviate from the equilibrium state in a short period, but in the long term, there maintains a balanced relationship between national innovation capability and transnational R\&D institution embedding.

According to the above analysis, we can conclude that there exists Johansen co-integration relationship between international trade, foreign direct investment, transnational R\&D institution embedding and national innovation capability.

\section{Granger Causality Test of Transnational Technology Transfer \& Diffusion and National Innovation Capability}

According to the above Johansen co-integration test results, we know that there exists co-integration relationship between transnational technology transfer \& diffusion and national innovation capability, but the function directions of the relationship between them are to be further tested. In the following, we examine the Granger causality of the three key elements of transnational technology transfer \& diffusion with national innovation capability respectively. Table 3 shows the test results of the relationship (Chen, He \& Wang, 2011).

Table 3. The Granger causality test results of the three elements of transnational technology transfer \& diffusion with national innovation capability

\begin{tabular}{|c|c|c|c|}
\hline Null hypothesis: & Lag & F statistics & P-value \\
\hline International trade is not Granger cause of national innovation capability & \multirow{2}{*}{1} & 3.56861 & 0.07837 \\
\hline National innovation capability is not Granger cause of international trade & & 7.33316 & 0.01620 \\
\hline International trade is not Granger cause of national innovation capability & \multirow{2}{*}{2} & 6.94620 & 0.00991 \\
\hline National innovation capability is not Granger cause of international trade & & 4.32771 & 0.03845 \\
\hline International trade is not Granger cause of national innovation capability & \multirow{2}{*}{3} & 6.75208 & 0.01111 \\
\hline National innovation capability is not Granger cause of international trade & & 5.25987 & 0.02273 \\
\hline Foreign direct investment is not Granger cause of national innovation capability & \multirow{2}{*}{1} & 10.9965 & 0.00470 \\
\hline National innovation capability is not Granger cause of Foreign direct investment & & 8.74392 & 0.00979 \\
\hline Foreign direct investment is not Granger cause of national innovation capability & \multirow{2}{*}{2} & 4.34101 & 0.03815 \\
\hline National innovation capability is not Granger cause of Foreign direct investment & & 4.32259 & 0.03856 \\
\hline Foreign direct investment is not Granger cause of national innovation capability & \multirow{2}{*}{3} & 2.53075 & 0.12269 \\
\hline National innovation capability is not Granger cause of Foreign direct investment & & 8.27588 & 0.00591 \\
\hline Transnational R\&D institutions embedding is not Granger cause of national innovation capability & \multirow{2}{*}{1} & 3.48402 & 0.08164 \\
\hline National innovation capability is not Granger cause of Transnational R\&D institutions embedding & & 2.72611 & 0.11950 \\
\hline Transnational R\&D institutions embedding is not Granger cause of national innovation capability & \multirow{2}{*}{2} & 1.08033 & 0.37033 \\
\hline National innovation capability is not Granger cause of Transnational R\&D institutions embedding & & 0.39170 & 0.68424 \\
\hline Transnational R\&D institutions embedding is not Granger cause of national innovation capability & \multirow{2}{*}{3} & 0.13736 & 0.93519 \\
\hline National innovation capability is not Granger cause of Transnational R\&D institutions embedding & & 0.36871 & 0.77753 \\
\hline
\end{tabular}

From table 3 we can find that: (1) whether in short-term or long-term, international trade and national innovation capability are mutually Granger causality. (2) In the short term (in 2 years), foreign direct investment and national innovation capability are mutually Granger cause, but in the long term (three years or more) national innovation capability is the Granger cause of foreign direct investment, and foreign direct investment is not the Granger cause of national innovation capability. (3) In the short term (1 year and less), transnational R\&D 
institutions embedding is the Granger cause of national innovation capability, but in the longer term (2 years and above), transnational R\&D institutions embedding and national innovation capability are not mutually Granger cause.

\section{Conclusions and Policy Implications}

\subsection{The Main Conclusions}

This study established a basic framework of analyzing the function mechanism of transnational technology transfer \& diffusion with national innovation capability, and analyzed the nine function paths of them. It also tests the Johansen co-integration and Granger causality between transnational technology transfer \& diffusion and national innovation capability empirically using the sample data of 1993-2011 in China. According to the analysis and test, we draw the following two conclusions:

(1) There exists a long-term equilibrium relationship (Johansen co-integration) between transnational technology transfer \& diffusion and national innovation capability. There exists Johansen co-integration relationship between the three elements (international trade, foreign direct investment and transnational R\&D institutions embedding) of transnational technology transfer \& diffusion of and national innovation capabilities. That means national innovation capability and the three elements of technology transfer $\&$ diffusion may deviate from the equilibrium state in a short period, but in the long term, there maintains a balanced relationship between national innovation capability and the three elements of technology transfer \& diffusion.

(2) There exists different Granger causality relationship between transnational technology transfer \& diffusion and national innovation capability. Whether in short or long term, the improvement of international trade or national innovation capability can promote the other elements, and there exists current effect and long-term effect between them. In the short term ( 2 years), foreign direct investment and national innovation capacity can promote each other, but in the long term ( 3 years and above) national innovation capability can promote the growth of foreign direct investment, and the growth of foreign direct investment can not effectively enhance national innovation capability. In a very short period of time (1 year and less), the increase of transnational R\&D institutions embedding can improve national innovation capability shortly, but in the longer term (2 years and above), there does not exist mutually reinforcing effect between transnational R\&D institutions embedding and national innovation capability, and this suggests that there only exists very limited spot effect of transnational $R \& D$ institutions embedding on the host country's national innovation capability building, and there is no very obvious long-term positive effects (Note 1).

\subsection{Policy Implications}

According to the test results and conclusions of the above relationship analysis, we conclude the following policy implications though in-depth analysis and assessment:

(1) Whether in short or long term, the improvement of international trade is conducive to enhancing the national innovation capability, in the meanwhile enhancing the national innovation capability is also conducive to the promotion of international trade. So, it is a win-win relationship between the international trade and national innovation capability.

(2) In the short term, increase the introduction of foreign direct investment is in favor of national innovation capability, but in the long term, foreign direct investment is not conducive to national innovation capability. But both in short or long term, national innovation capacity is conducive to enhancing the conduct of foreign direct investment. This shows that only continuous improvement of national innovation capability can really attract foreign direct investment, but foreign direct investment is to pursue more interests, so in short term it has a certain role in promoting the host country's innovation capability, but in the long term, foreign direct investment is not committed to the improvement of the host country's national innovation capability.

(3) In a very short period, foreign R\&D institutions embedding in the host country's national innovation system has a certain role in promoting the host country's innovation capability, but in a slightly longer term, foreign R\&D institutions embedded in the host country does not have much role in promoting the host country's national innovation capability, which may be related with that transnational R\&D focused on the acquisition of knowledge and technology from the host country and innovation system, and does not want to provide knowledge and technology for the host country using an open attitude. Whether in short or long term, the improvement of the host country's innovation capability has no greater promotion role on the transnational R\&D institutions embedded in the host country's innovation system, and on the one hand this may be because of the sample data's defect, or it is the special result of China, on the other hand may because of the dynamic of transnational R\&D institutions embedded in the host country does not come from the improvement of the host 
country's innovation capability, but from other factors such as the host country's economic development enhancements.

\section{Acknowledgements}

This study is supported by the following fund: National Natural Science Foundation of China "A theoretical and empirical research on the mode and its effects of transnational R\&D Center embedding in China's national innovation system" (project number: 71073178).

\section{References}

Chang, Y., \& Chen, W. (2011). Research on functional mechanism of intellectual capital on regional innovation capability. Techno-Economic, 30(7), 1-8.

Chen, J., \& Wu, N. N. (1999). Effects Analysis on Multinational Technology Diffusion in China. APEC Research, 1, 76-79.

Chen, W., \& Wang, X. J. (2010). Regional Intellectual Capital and Regional Innovation Capability—Relationship and Empirical Research of their impact. Techno-Economic, 29(2), 22-27, 53.

Chen, W., He, Q. F., \& Wang, X. J. (2011). The relationship of national intellectual capital and national innovation capacity-An empirical study based on China's 20-year panel data. Chinese Science and Technology Forum, 4, 25-31.

Cui, X. J. (2011). The Situation and Policy Recommendations on Foreign R\&D centers in China. Beijing: People Publishing House.

Das, S. (1987). Externalities and technology transfer through multinational corporations: a theoretical analysis. Journal of International Economics, 22(1), 171-182. http://dx.doi.org/10.1016/0022-1996(87)90028-6

Hymer, S. (1970). The efficiency (contradictions) of multinational corporations. The American Economic Review, 60(2), 441-448.

Jiang, X. J. (2004). The impact on the improvement of Chinese industrial technology research and development capabilities of attracting foreign investment. International Economic Review, 3(4), 13-18.

Jiang, X. J., \& Li, R. (2002). The contribution of FDI on China's industrial growth and technological progress. China Industrial Economy, 7, 5-16.

Lall, S. (1987). Learning to industrialize: the acquisition of technological capability by India. London: Macmillan.

Moran, T. H. (1978). Multinational corporations and dependency: a dialogue for dependentistas and $\begin{array}{llll}\text { non-dependentistas. } & \text { International } & \text { Organization, } & \text { 32(1), }\end{array}$ http://dx.doi.org/10.1017/S0020818300003878

Peng, J. S., \& Liu, C. L. (2003). Cold Thoughts on multinational technology transfer to China. Research and Development Management, 15(6), 79-84.

Peng, J. S., Sun, W. X., \& Zhong, W. G. (2008). An empirical study on China Technology Innovation Policy evolution and Performance (1978-2006). Research Management, 29(4), 134-150.

Streeten, P. A. (1977). Changing Perceptions of Development. Challenge, 20(5), 63-66.

Wang, J. Y., \& Blomström, M. (1992). Foreign investment and technology transfer: A simple model. European economic review, 36(1), 137-155. http://dx.doi.org/10.1016/0014-2921(92)90021-N

Wang, X. J., \& Chen, W. (2008). Relationship of Regional Intellectual Capital and Regional Innovation Capability-An Empirical Study Based on Hubei Province. China Industrial Economy, 9, 25-36.

Wang, X. J., \& Chen, W. (2010). Regional Intellectual Capital and Regional Innovation Capability - Index System Formulation and Their Relationship. Management Engineering, 24(3), 1-6.

Wang, Z. J., \& Zhang, W. (2002). Foreign direct investment, technology licensing and technology innovation. Economic Research, 3, 69-75.

Xie, F. J., \& Zheng, S. L. (2000). Study on FDI Technology Transfer System. Scientific Management Research, $2,7-11$.

Xie, W. (2002). The evaluation framework of the effectiveness of technology transfer of Foreign Direct Investment. Scientific Management Research, 2, 35-39. 
Yan, L. F. (2010). Multinational technology transfers and their impact: a review. Financial Economics, 20(6), $36-37$.

Zheng, X. P. (2006). Research Review on National Innovation System. Scientific Management Research, 24(4), $1-5$.

\section{Note}

Note 1. Usually we think that the improvement of the host country's innovation capability will help attract transnational R\&D institutions embedding, because transnational R\&D institutions may acquire knowledge and technology innovation through embedding in the host country's innovation system. However, the empirical results here are not consistent with the general understanding, perhaps it is the real situation, perhaps there is defective of the research object or the sample.

\section{Copyrights}

Copyright for this article is retained by the author(s), with first publication rights granted to the journal.

This is an open-access article distributed under the terms and conditions of the Creative Commons Attribution license (http://creativecommons.org/licenses/by/3.0/). 